\title{
Curious complication in a case of congenital diaphragmatic hernia
}

\author{
Celia Wanda Kariuki, Soume Bhattacharya
}

Department of Paediatrics, Western University, London, Ontario, Canada

Correspondence to Dr Soume Bhattacharya; Soume.Bhattacharya@|hsc.on.ca

Accepted 9 November 2021
Check for updates

(C) BMJ Publishing Group Limited 2021. No commercial re-use. See rights and permissions. Published by BMJ.

To cite: Kariuki CW, Bhattacharya S. BMJ Case Rep 2021;14:e246814 doi:10.1136/bcr-2021 246814

\section{DESCRIPTION}

A male infant with an antenatally diagnosed leftsided congenital diaphragmatic hernia $(\mathrm{CDH})$ was born at a tertiary level neonatal intensive care unit (NICU) at 37 weeks and 5 days gestation with a birth weight of 3140 g. Neonatal resuscitation was uneventful with Apgar scores of 7 and 8 at 5 and $10 \mathrm{~min}$, respectively. The infant demonstrated signs of respiratory distress and was intubated and ventilated as per standard management guidelines. ${ }^{1}$ Standard neonatal care was established including maintaining normothermia and establishment of indwelling lines that is, an umbilical arterial line (UAC) and an umbilical venous catheter (UVC). The double lumen 5 FG UVC was inserted to a depth of $10.5 \mathrm{~cm}$. On abdominal X-ray, the UVC projected over the left upper quadrant, with a query of being situated within the left portal vein, the leftward deviation being attributed to the abnormal liver position. In the first few hours of life, the infant showed signs of acute pulmonary hypertension consistent with $\mathrm{CDH}$ diagnosis, confirmed by echocardiography, with oxygen needs ranging from 0.6 to 1.0 on mechanical ventilator. He was started on inhaled nitric oxide (iNO) at $20 \mathrm{ppm}$ with good clinical response and infant remained well with excellent haemodynamic stability and $\mathrm{FiO}_{2}$ ranging between 0.25 and 0.40 .

Clinical instability was noted at 36 hours of life with hypotension and reduced urine output. The infant received three normal saline boluses and was started on infusions of epinephrine, vasopressin and intravenous hydrocortisone. There was a concomitant increase in $\mathrm{FiO}_{2}$ from 0.3 to 1.0, re-emergence of oxygen saturation lability and development of abdominal distention. This clinical deterioration was initially attributed to worsening of $\mathrm{CDH}$ disease process. Targeted neonatal echocardiography performed as part of a neonatal haemodynamic consultation revealed systemic to supra-systemic pulmonary pressures with low cardiac output.

Interestingly, the most striking finding of the echocardiography was a significant fluid collection mostly in the left thoracic cavity in the standard parasternal views (figure 1). The fluid contained swirling particulate echogenic debris classical of Total Parenteral Nutrition (TPN) and lipid extravasation, with a significant collection of similar fluid seen in the abdominal cavity as well (figure 2). The possible aetiology was UVC extravasation with abdominal collection of TPN and lipids. The UVC, on checking appeared to have no free back flow of blood and was immediately removed. The unique anatomy of neonates with diaphragmatic hernia ${ }^{2}$

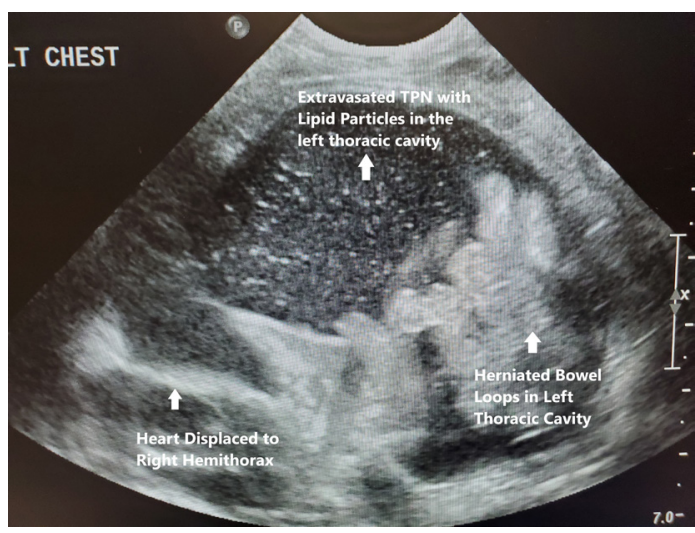

Figure 1 Massive fluid accumulation seen in left thoracic cavity with floating loops of herniated bowel characteristic of congenital diaphragmatic hernia.

allowed the extravasated abdominal fluid to pass across the diaphragmatic defect and collect in the thoracic cavity, causing further collapse of the left lung and tamponade effect on the left ventricle. A total of $190 \mathrm{~mL}$ of TPN and lipid emulsion was retrieved in two steps, starting with abdominal paracentesis (aspirate volume $100 \mathrm{~mL}$ ), then thoracentesis using a chest tube (aspirate volume 90 $\mathrm{mL}$ ) under ultrasound guidance, with no need for indwelling catheters.

Within 15 min of drainage there was an improvement in preductal and postductal saturations and improved oxygen requirement from 1.0 to 0.30 baseline. Stable haemodynamic parameters allowed inotrope and pressor support to be weaned within 24 hours. On day 9 of life the infant underwent successful surgical repair of the $\mathrm{CDH}$ and was discharged home on day 32 of life.

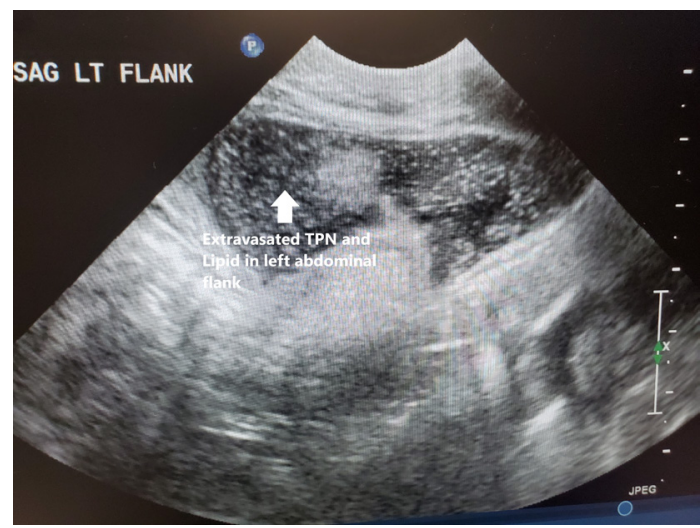

Figure 2 Fluid collection with particulate shining debris classic of lipid and TPN seen in the abdominal cavity. 


\section{Learning points}

- The underlying cause of rapid clinical deterioration in this case of congenital diaphragmatic hernia was TPN extravasation from a malpositioned umbilical venous catheter. Such complications should be considered as a differential diagnosis when umbilical lines are not in ideal positions on radiographs.

- This case was unique due to the anatomical distribution of the extravasated fluid simultaneously in the abdomen and the thorax, as a direct result of the diaphragmatic defect.

- Point of care echocardiographic/ultrasonographic images may have a crucial role in revealing the underlying aetiology and facilitating timely lifesaving intervention in critically unwell neonates.
Contributors CK involved in clinical management, obtaining consent, collecting pertinent data and preparing first draft of manuscript. SB lead in clinical management, obtained the ultrasonographical data and finalising manuscript.

Funding The authors have not declared a specific grant for this research from any funding agency in the public, commercial or not-for-profit sectors.

Competing interests None declared.

Patient consent for publication Consent obtained from parent(s)/guardian(s). Provenance and peer review Not commissioned; externally peer reviewed.

Case reports provide a valuable learning resource for the scientific community and can indicate areas of interest for future research. They should not be used in isolation to guide treatment choices or public health policy.

\section{REFERENCES}

1 Canadian Congenital Diaphragmatic Hernia Collaborative, Puligandla P, Skarsgard $\mathrm{E}$, et al. Diagnosis and management of congenital diaphragmatic hernia: a clinical practice guideline. CMAJ 2018;190:E103-12.

2 McHoney M. Congenital diaphragmatic hernia. Early Hum Dev 2014;90:941-6.

Copyright 2021 BMJ Publishing Group. All rights reserved. For permission to reuse any of this content visit https://www.bmj.com/company/products-services/rights-and-licensing/permissions/

BMJ Case Report Fellows may re-use this article for personal use and teaching without any further permission.

Become a Fellow of BMJ Case Reports today and you can:

- Submit as many cases as you like

- Enjoy fast sympathetic peer review and rapid publication of accepted articles

- Access all the published articles

Re-use any of the published material for personal use and teaching without further permission

Customer Service

If you have any further queries about your subscription, please contact our customer services team on +44 (0) 2071111105 or via email at support@bmj.com.

Visit casereports.bmj.com for more articles like this and to become a Fellow 